\title{
COMPARATIVE ANALYSIS FROM THE PERSPECTIVE OF TOURISTS IN THE ALL- INCLUSIVE SYSTEM IN CANCUN, MEXICO, AND PUERTO PLATA, DOMINICAN REPUBLIC
}

\author{
Francisco Orgaz-Agüera ${ }^{1}$ \\ Tomás López-Guzmán² \\ José Francisco Domínguez Estrada ${ }^{3}$ \\ Manuel Alector Ribeiro ${ }^{4}$
}

\begin{abstract}
The all-inclusive system has been highly developed in different countries of the Caribbean. This paper shows a comparative analysis of two established destinations such as Cancun and Puerto Plata in order to know the sociodemographic profile and valuation of the all-inclusive system of tourists visiting these areas. The main results show the high degree of satisfaction with the trip because of the convenience that this system gives clients and the knowledge of the spending budget prior to the travel. An aspect to improve stands out as the need to strengthen the interaction between the local community and travellers.
\end{abstract}

Keywords: All-inclusive systems. Hotels-resorts. Tourist motivations. Caribbean.

\section{Cite it like this:}

Orgaz-Agüera, F., López-Guzmán, T., Domínguez Estrada, J., \& Alector Ribeiro, M. (2018). Comparative Analysis from the Perspective of Tourists in the All-Inclusive System in Cancun, Mexico, and Puerto Plata, Dominican Republic. PODIUM Sport, Leisure And Tourism Review, 7(2), 178-192. https://doi.org/10.5585/podium.v7i2.277

${ }^{1} \mathrm{PhD}$ in Tourism at University of Seville, (Spain). E-mail: franorgaz@utesa.edu, ORCID ID: https://orcid.org/0000-0002-4240-8640

${ }^{2}$ Doctor in Economics by the Universidad Nacional de Educación a Distancia - UNED. (Spain). E-mail: tomas.lopez@uco.es, ORCID ID: https://orcid.org/0000-0001-8800-8223

${ }^{3}$ Bachelor of Tourism and Researcher in tourism at University of Caribe, (Mexico). E-mail: fdominguez@ucaribe.edu.mx

${ }^{4} \mathrm{PhD}$ in Tourism Studies at the University of Algarbe - UAlg, (Portugal). E-mail: m.ribeiro@surrey.ac.uk, ORCID ID: https://orcid.org/0000-0003-4484-1082 


\section{ANÁLISIS COMPARATIVO DE LA PERSPECTIVA DE TURISTAS EN EL SISTEMA ALL- INCLUSIVE EN CANCUN, MÉXICO Y PUERTO PLATA, REPÚBLICA DOMINICANA}

\section{RESUMEN}

El sistema todo incluido ha sido altamente desarrollado en diferentes países del Caribe. Este documento muestra un análisis comparativo de dos destinos consolidados, como Cancún y Puerto Plata, con el fin de conocer el perfil sociodemográfico y la valoración del sistema todo incluido de turistas que visitan estas áreas geográficas. Los principales resultados muestran el alto grado de satisfacción con el viaje debido a la conveniencia que este sistema brinda a los clientes y al conocimiento del presupuesto de gastos antes del viaje. Un aspecto a mejorar se destaca por la necesidad de fortalecer la interacción entre la comunidad local y los viajeros.

Palabras clave: Sistemas todo incluido. Hoteles-resorts. Motivaciones turísticas. Caribe.

\section{ANÁLISE COMPARATIVA DA PERSPECTIVA DE TURISTAS NO SISTEMA ALL- INCLUSIVE EM CANCUN, MÉXICO E PUERTO PLATA, REPÚBLICA DOMINICANA}

\section{RESUMO}

Análise comparativa do ponto de vista dos turistas no sistema all-inclusive em Cancun, México, e Puerto Plata, República Dominicana. O sistema all-inclusive tem sido altamente desenvolvido em diferentes países do Caribe. Este documento mostra uma análise comparativa de dois destinos consolidados, como Cancún e Puerto Plata, a fim de conhecer o perfil sociodemográfico e a avaliação do sistema all-inclusive de turistas que visitam essas áreas geográficas. Os principais resultados mostram o alto grau de satisfação com a viagem devido à conveniência que este sistema oferece aos clientes e ao conhecimento do orçamento de despesas antes da viagem. Um aspecto a melhorar é destacado pela necessidade de fortalecer a interação entre a comunidade local e os viajantes.

Palavras chave: Sistemas com tudo incluído. Hotéis-resorts. Motivações turísticas. Caribe. 


\section{INTRODUCTION}

Tourism in certain destinations has meant a strong socioeconomic development, sometimes even changing their own economic structure. It is therefore important to analyse, from the academic point of view, both the tourist profile to which it is addressed and the type of offer that is presented at the destination. In this regard, in recent years in certain geographical areas a type of offer based on allinclusive hotel-resorts where tourists know in advance the final cost of their trip and where most of their needs during the trip are covered, are being developed. This system has spread across different areas and countries, and in this sense, it is quite competitive among the various destinations. The all-inclusive system (AIS) has its origin in the holiday camps in Britain during the 1930s and later in the Club Méditerranée in the 50s of the twentieth century (Issa \& Jayawardena, 2003). But its great development occurred in the Caribbean, starting in Jamaica in the 70s of the twentieth century, complemented further by the image of sun and sand and hospitality of this geographic area (Ayik, Benetatos \& Evagelou, 2013).

Two of the most popular areas in this type of tourism in the Caribbean are the State of Quintana Roo in Mexico and Dominican Republic. In fact, hotel chains that manage resorts in these destinations belong mostly to the same companies, usually European or American capital and, also, travel agencies offer these two destinations as competing with each other with similar prices. The main problem of this investigation is the ignorance of the perception of the tourists that visit these hotels, above all, the lack of knowledge of their attitudes and motivations. This research is relevant because, based on the perception of tourists, new activities complementary to sun and beach tourism can be generated, diversifying the offer in these destinations.

The aim of this paper is to present a comparative analysis of the AIS in the two consolidated tourist destinations that compete among themselves, Cancun (Mexico) and Puerto Plata (Dominican Republic). So, this paper shows the results of a fieldwork conducted simultaneously in the two locations to find the sociodemographic profile of foreign tourists visiting one of these two areas and the assessments by AIS tourists of each of these geographic areas with regard to this system. To achieve this goal, this article is structured after this introduction, with a second section where a review of the existing literature on AIS is made; a third section that provides a description of the geographic areas under study; a fourth section which shows the methodology used and a fifth section which presents the results of the research. This paper ends with conclusions and bibliographical references obtained.

\section{LITERATURE REVIEW}

The AIS is a product aimed at international tourism markets based mainly on minimizing currency transactions during the holidays. The basic features of this system is based on including in the final price paid by tourists, which usually takes place in their own town, lodging, food, drinks and a range of tourist services (González Herrera \& Palafox Muñoz, 2007) and it works especially in coastal destinations (Anderson, 2010), which are characterized by their low public security or because there is no attractive complementary offer outside the hotel, especially in catering and leisure (González Herrera \& Palafox Muñoz, 2007), although in recent years it has spread to regions where there are a wide complementary services such as certain areas in the Iberian Peninsula (Spain and Portugal), which has generated considerable debate about the positive and negative effects of this system in these geographical areas.

Currently the AIS has great development in the Caribbean, in different Mediterranean countries, both European and 
African, and in certain geographical areas of Africa and Southeast Asia (mainly in Indonesia and Thailand) (González Herrera and Palafox Muñoz, 2007), being Europe and North America the major emitting countries of this type of tourists (Anderson, 2010), and fundamentally travellers with an average level of income (Ayik et al., 2013). Along with this, the All-Inclusive concept, in addition to coastal areas in recent years, is also being developed on cruises (Issa \& Jayawardena, 2003) and through some tour packages (Wong \& Kwong, 2004). Scientific literature documents AIS studies in Jamaica (Smith \& Spencer, 2011), Dominican Republic (Moreno Gil, Celis Sosa \& Aguiar Quintana, 2002), other Caribbean countries (Chamber \& Airey, 2001), Mexico (González Herrera \& Palafox Muñoz, 2007), Spain (Alegre \& Pou, 2006; Anderson, 2012), Romania (Condratov, 2014), Turkey (Özdemir, Çizel \& Çizel, 2012) and Malta (Chapman \& Speake, 2011).

Among the positive effects of the AIS we find an increase in revenues of tour operators and travel agencies, the creation of opportunities for tourists to travel at a not very expensive and known in advance price, increased occupancy rates of resorts, the possibility of introducing other cultural products through offering excursions handled from the hotel itself and the simplification of monetary relations between the hotel and guests (Alegre \& Pou, 2006). And as negative effects, we find a decrease in the quality of the tourism product, decreased staff motivation, lack of interaction between the tourists, mainly foreigners, and the local community (Çiftçi, Düzakin \& Önal, 2007) and, furthermore, that this system is not suitable for small hotels given that hotel needs to have at least 150 hotel rooms to make the system profitable (Anderson, 2010). Wong Kwong (2004) notes that the AIS is well accepted by tourists travelling from countries with different cultures as they know the type of resort they will find in their holiday place, although they are generally quite dissatisfied with the limited experience to learn about other cultures in these trips due to the little or non-interaction with the local community. Likewise, it can also be a great disadvantage for those who have a nutritional diet (Condratov, 2014).

The AIS is primarily a tourist product and must be defined as such (Alegre \& Pou, 2006). This implies a major change and restructuring of supply at destination (Alegre \& Pou, 2006), mostly due to the virtual disappearance of the catering industry as a result of a change in the flow of services offered at the destination, as the hotel establishment keeps hold of an important part of that flow. In that sense, it is essential to tourist satisfaction finding quality in the hotel where they stay itself, including the cuisine offered to tourists in the hotel and the variety of beverages that are served free of charge at the hotel itself (Ayik et al, 2013), and not being as important elements such as cultural, natural, historical, etc. elements found in the destination at the time of choosing the resting place of the traveller (Ayik et al., 2013).

The AIS is being consolidated in many destinations due to the prospect that consumers know exactly what they pay before leaving (Çizel, Çizel, Sarvan \& Ozdemir, 2013), the important role in this system of travel intermediaries (Çizel et al., 2013) since this type of product is targeted to different types of customers such as couples, families, young people, pensioners, etc. (Çiftçi et al., 2007). Also, this system is implying an opportunity for tourism development in Developing Countries (Çizel et al., 2013), although one of the fundamental aspects to analyse, and debate are trade relations between the resorts and the suppliers of goods and services in the local community (Anderson, 2010) to determine what the economic flows that would eventually go into the local businesses would be.

\section{DESCRIPTION OF THE GEOGRAPHIC AREA}

This research was conducted simultaneously in two geographical areas, Cancun in Mexico and Puerto Plata in Dominican Republic, both located in the Caribbean (Figure 1). 
Figure 1. Geographical location of Cancun and Puerto Plata.

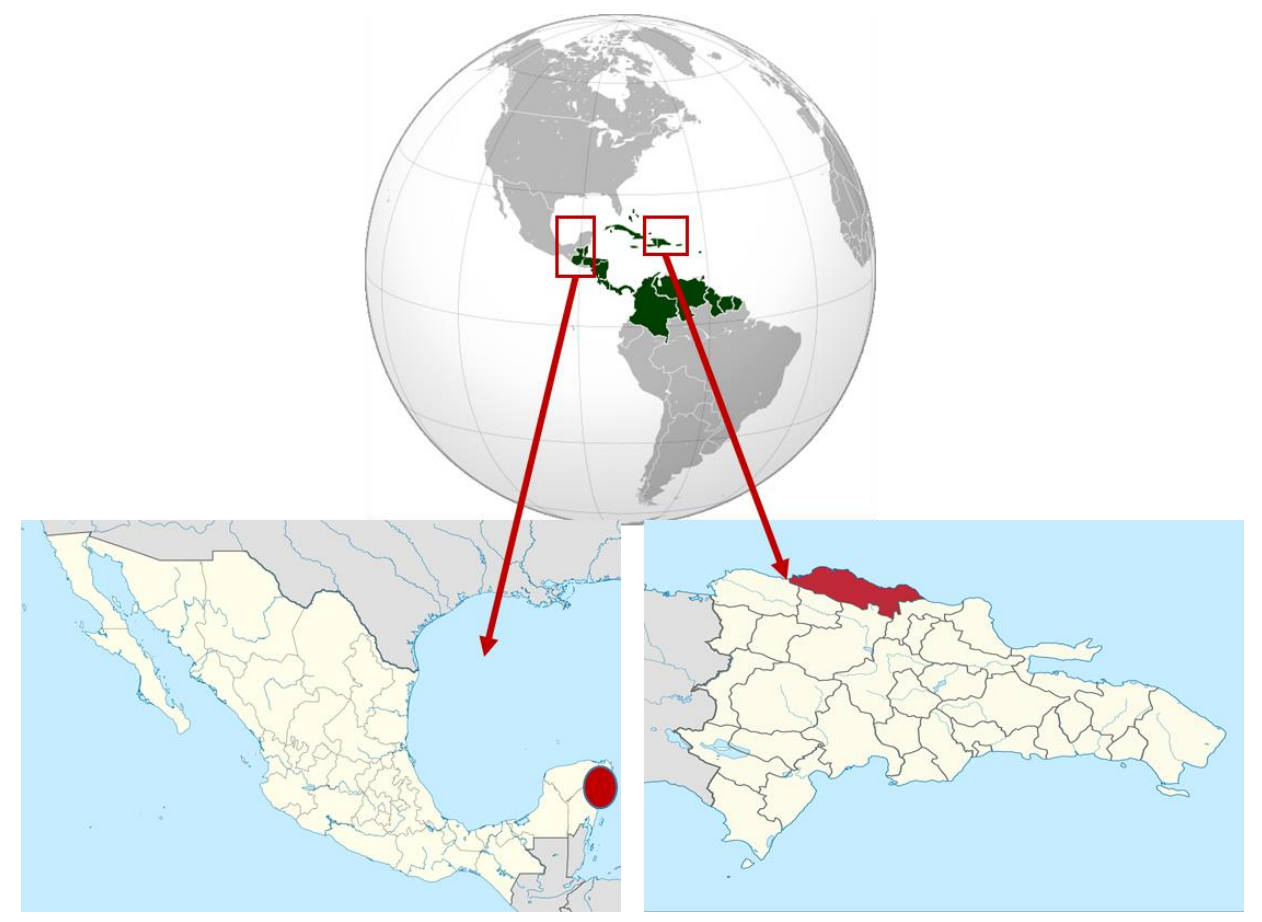

Source: Own elaboration

Cancun is a traditional tourist destination that is located on the Northeast coast of Quintana Roo in eastern Mexico and whose white sand beaches are the main attraction. Thus, next to the beaches, there are 145 hotels, with a total of 30,608 rooms (SEDETUR, 2014). This tourism destination has been analysed in different researches, including, inter alia, those related to the economy (Gormsen, 1982; Torres, 2002), the origins of tourism (Espinosa-Coria, 2013), natural disasters (Babinger, 2012) or accommodation (Lagunas Puls, Ramírez Pacheco \& Sonda de la Rosa, 2014). The emphasis on academic research to this area is logical given that Cancun is one of the main destinations within the State of Quintana Roo. The number of tourists arriving to different destinations of Quintana Roo in the period 2012-2013 is shown in Table 1.

Table 1. Number of tourists in the destinations of Quintana Roo, 2012-2013.

\begin{tabular}{|c|c|c|c|}
\hline Destination & Year 2012 & Year 2013 & Difference \% \\
\hline Riviera Maya & $3,895,548$ & $4,158,135$ & $6.7 \%$ \\
\hline Cancun & $3,642,449$ & $4,093,942$ & $0.4 \%$ \\
\hline Cozumel & 445,974 & 447,747 & $-7.0 \%$ \\
\hline Chetumal & 476,465 & 443,079 & $48.7 \%$ \\
\hline Women Islands & 180,522 & 268,360 & $8.9 \%$ \\
\hline Total Quintana Roo & $8,640,958$ & $9,411,263$ & $12 \%$ \\
\hline
\end{tabular}

Source: SEDETUR (2014) 
As it can be seen in Table 1, in 2013 Cancun received more than 4 million tourists, reflecting an increase of $12.4 \%$ over the previous year. You may also notice that Cancun is the second destination in tourist arrivals in the State of Quintana Roo, only behind Riviera Maya, although with a very small difference between destinations compared to others (Cozumel, Chetumal and Women Islands). Therefore, from a total of 9,411,263 million tourists arriving in the state of Quintana Roo, $44.2 \%$ came to Riviera Maya and $43.5 \%$ to Cancun. Regarding the hotel occupancy in Cancun, this destination increased from $72.5 \%$ in 2012 to $76.8 \%$ in 2013, representing an increase of $4.3 \%$ and only behind Riviera Maya (81.0\%). The average stay of tourists in this destination in 2013 is 5.1 nights, up by $0.2 \%$ to 2012 and still one day less than in Riviera Maya (SEDETUR, 2014).
Therefore, Cancun is considered one of the main all-inclusive sun and beach tourist destinations internationally, one of the most outstanding in the whole Caribbean since the opening of its first all-inclusive hotel in 1974 (Babinger, 2012).

The other analysed area is Puerto Plata in Dominican Republic. The Dominican Republic is located, along with Haiti on the $L a$ Española island, in the Caribbean (Map 1). In this country, we can highlight the sun and beach tourism, especially in the areas of Bavaro-Punta Cana and Puerto Plata, having received in 2015 a total of $5,599,859$ visitors (ASONAHORES, 2016), thus confirming its steady growth. The number of visitors coming to the country, the number of overnight stays and tourist daily average expenditure is presented in Table 2 (expressed in dollars) for the period 2009-2015.

Table 2. Visitor arrivals to Dominican Republic for 2009-2015

\begin{tabular}{|c|c|c|c|c|c|c|c|}
\hline Year & $\mathbf{2 0 0 9}$ & $\mathbf{2 0 1 0}$ & $\mathbf{2 0 1 1}$ & $\mathbf{2 0 1 2}$ & $\mathbf{2 0 1 3}$ & $\mathbf{2 0 1 4}$ & $\mathbf{2 0 1 5}$ \\
\hline Visitors & $3,992,303$ & $4,124,543$ & $4,306,431$ & $4,562,606$ & $4,689,770$ & $5,141,377$ & $5,599,859$ \\
\hline $\begin{array}{c}\text { Average daily } \\
\text { tourist } \\
\text { spending (in } \\
\text { dollars) }\end{array}$ & 107.02 & 107.24 & 109.11 & 112.22 & n.a. & n.a & n.a \\
\hline
\end{tabular}

Source: Own elaboration from data of ASONAHORES (2016)

n.a.: Data not available

Table 2 shows that the number of visitors has steadily increased, as did the average expenditure of tourists, ranking in 2012, the latest data available, at $\$ 112.22$ per day.

The area under study is Puerto Plata (map 1), located in the north of the country. According to Roessingh and Duijnhoven (2004), this destination along with Punta Cana are configured as the two most important areas for sun and beach in Dominican Republic, both destinations offering all-inclusive hotels. Thus, according to these authors, the rise of this type of tourism in Puerto Plata came from the eighties of the last century with the construction of an international airport in this area, making it accessible to transport tourists to this destination. In 2013, the airport received a total of 353,857 visitors (ASONAHORES, 2016), becoming the third most important in 
the country after the airports of Punta Cana and Santo Domingo.

In this sense, according to data from ASONAHORES (2016), Puerto Plata had an average hotel occupancy rate in 2013 of $55.5 \%$, which is lower than the national average (71.7\%), and the months of January (73.3\%), February $(81.1 \%)$, March $(82.2 \%)$ and April $(67.2 \%)$ standing out as these refer to the peak season for this destination. On the other hand, according to ASONAHORES (2016), the province of Puerto Plata has 20 hotel resorts of various international chains, mainly European and North-American. At these all-inclusive hotel resorts you can also hire complementary activities to carry out outside the hotel, with emphasis on excursions where you visit the Natural Monument of Damajagua Falls, the Natural Monument Isabel de Torres, the Ocean World Adventure Park or the city of Puerto Plata.

\section{METHODOLOGY}

The methodology used in this research is based on fieldwork carried out in order to meet the sociodemographic profile and assessment by foreign tourists visiting two destinations (Puerto Plata in Dominican Republic and Cancun in Mexico) in the allinclusive system.

The fieldwork consisted of surveys to tourists who were in the main beaches of the geographic area of Puerto Plata and Cancun. These beaches have been selected because these beaches have received an increased number of foreign tourists since the major AllInclusive hotels of this area are located near them. On these beaches, there are many hotel resort and, for that reason and prior to the completion of fieldwork, previous meetings were conducted with hotel managers to explain the purpose of this investigation and to ask for their collaboration to conduct the surveys in the different bounded areas that each hotel has on the beaches.
The surveys were conducted personally to foreign tourists staying in different AllInclusive hotels, and these were recognised by the interviewers through the appropriate identification "bracelet" of the hotel where they were staying. The surveys were conducted with all resorts and hotels available of the two destinations. Prior to the completion of the questionnaire, the interviewer informed the target tourist of the investigation and requested their cooperation therein. The questionnaire was written in four languages (English, Spanish, French and German), because all the questionnaires were translated by the Languages Department of the Technological University of Santiago (Dominican Republic). Tourists completed the questionnaire completely independently and anonymously. The fieldwork was conducted simultaneously in the two geographical areas under study, it developed during the months of March, April and May 2014 through convenience sampling, technically commonly used in this type of research, where Respondents are available to be interviewed in a period of space and time (Finn, Elliott-White \& Walton, 2000).

The structure of the survey used in this research is based on various previous studies (Anderson, 2012; Kozak, 2002; Özdemir et al., 2012) and addresses three distinct parts: first, the details of the trip, which sought to know aspects like the structure of the trip, its duration or the reason for the visit; second, the opinion and evaluation of the all-inclusive concept, analysing the strengths and weaknesses of this system, and assessing some aspects of the destination; and third, the sociodemographic characteristics of tourists. Thus, the total number of items was 63. A pretest was conducted on 30 surveys. In total, the number of valid questionnaires in the Puerto Plata area was 551 questionnaires, obtaining a confidence level of $95 \%$ and a sampling error of $4.17 \%$; and in the Cancun area 515, obtaining a confidence level of $95 \%$ and a sampling error of $4.32 \%$. Table 3 shows the data sheet of the research. 
Table 3. Technical table of the research

\begin{tabular}{|c|c|c|}
\hline Population & 353,857 foreign tourists & $4,093,942$ foreign tourists \\
\hline Geographic Area & Puerto Plata & Cancun \\
\hline Temporality & March-May 2014 & Convenience sampling \\
\hline Procedure & Convenience sampling & $95 \%$ \\
\hline Confidence level & $95 \%$ & $4.32 \%$ \\
\hline Sampling error & $4.17 \%$ & 515 \\
\hline Valid questionnaires & 551 & \\
\hline
\end{tabular}

Source: Own elaboration

The questions in the questionnaire that were intended to know the evaluation and opinions of tourists were answered through a Likert scale of five points. Questions about trip details were closed with different possible answers. Meanwhile, some items related to the sociodemographic profile of tourist items were closed, although there were two questions focused on whether or not to repeat the allinclusive experience and their opinion about this geographical area, which was answered openly. Cronbach's alpha was 0.818 and is therefore acceptable, since Nunally and Bernstein (1994) consider a scale acceptable if its Cronbach's alpha is above 0.7. The data from this research have been tabulated and analysed using the IBM SPSS 22 statistical system. Media analysis, frequencies, contingency analysis, $\mathrm{p}$-value and significance level have been performed.

\section{RESEARCH RESULTS AND DISCUSSION}

Key data corresponding to the sociodemographic characteristics of tourists surveyed in Cancun (Mexico) and Puerto Plata (Dominican Republic) are shown in Table 4, which are gender, age, education level, country of origin and respondent income level. 
Table 4. Sociodemographic profile of tourists in Cancun and Puerto Plata

\begin{tabular}{|c|c|c|c|c|}
\hline Variable & Variable & Cancun & Puerto Plata & $\begin{array}{l}\text { Contingency } \\
\text { coefficient (p- } \\
\text { value) }\end{array}$ \\
\hline Gender & $\begin{array}{l}\text { Male } \\
\text { Female }\end{array}$ & $\begin{array}{l}44.7 \% \\
55.3 \%\end{array}$ & $\begin{array}{l}46.8 \% \\
53.2 \%\end{array}$ & $\begin{array}{l}0.022 \\
(0,479)\end{array}$ \\
\hline Age & $\begin{array}{l}\text { Under } 30 \text { years old } \\
30-39 \text { years old } \\
40-49 \text { years old } \\
50-59 \text { years old } \\
60 \text { years old or more }\end{array}$ & $\begin{array}{l}31.5 \% \\
45.4 \% \\
22.7 \% \\
0.2 \% \\
0.2 \%\end{array}$ & $\begin{array}{l}37.0 \% \\
36.3 \% \\
21.4 \% \\
3.3 \% \\
2.0 \%\end{array}$ & $\begin{array}{l}0.165 \\
(0.000) *\end{array}$ \\
\hline $\begin{array}{l}\text { Level of } \\
\text { education }\end{array}$ & $\begin{array}{l}\text { Primary } \\
\text { Secondary } \\
\text { University }\end{array}$ & $\begin{array}{l}0.0 \% \\
4.7 \% \\
95.3 \%\end{array}$ & $\begin{array}{l}0.9 \% \\
15.6 \% \\
83.5 \%\end{array}$ & $\begin{array}{l}0.190 \\
(0.000) *\end{array}$ \\
\hline Country & $\begin{array}{l}\text { USA } \\
\text { UK } \\
\text { Spain } \\
\text { Argentina } \\
\text { Canada } \\
\text { Germany } \\
\text { Others }\end{array}$ & $\begin{array}{l}48.3 \% \\
36.1 \% \\
7.6 \% \\
2.9 \% \\
2.5 \% \\
0.0 \% \\
4.6 \%\end{array}$ & $\begin{array}{l}42.8 \% \\
21.2 \% \\
4.2 \% \\
0.0 \% \\
8.0 \% \\
8.3 \% \\
15.5 \%\end{array}$ & $\begin{array}{l}0.392 \\
(0.000) *\end{array}$ \\
\hline Income & $\begin{array}{l}\text { More than } \$ 2,500 \\
\text { From } \$ 1,501-2,500 \\
\text { From } \$ 1,001-1,500 \\
\text { From } \$ 700-1,000 \\
\text { Less than } \$ 700\end{array}$ & $\begin{array}{l}81.1 \% \\
11.9 \% \\
3.9 \% \\
3.1 \% \\
0.0 \%\end{array}$ & $\begin{array}{l}63.9 \% \\
19.2 \% \\
13.3 \% \\
3.4 \% \\
0.2 \%\end{array}$ & $\begin{array}{l}0.208 \\
(0.000) *\end{array}$ \\
\hline
\end{tabular}

Source: Own elaboration

* Correlation is significant at level 0.01 
According to Table 4, as for the age group, it stands out that in both areas they are under 50 years of age. As for their educational level, it is mainly emphasized that in Cancun more than $95 \%$ of tourists have a university degree, 12 points above the tourists surveyed in Puerto Plata. Similarly, with regard to the country of origin of tourists, in both areas Americans and British stand out. As for the travelling companion/s to the trip, most are with work colleagues or friends (Cancun, 40.8\%, Puerto Plata, 38.5\%) and a partner (Cancun, 32.6\%, Puerto Plata, 39, 0\%) and have chosen this destination largely on the recommendation of the travel agency (Cancun, $39.0 \%$, Puerto Plata, 29.8\%) and on the recommendation of family and friends
(Cancun, 28.3\%; Puerto Plata, 22.6\%). Furthermore, in the destination of Puerto Plata, we can stress the importance of Internet as a way to know this destination as $30.4 \%$ of tourists surveyed said they have known this destination via the Internet. On the other hand, for $73 \%$ of respondent tourists, this was their first visit to Puerto Plata while in the case of Cancun the percentage was $35.3 \%$. An association was detected between the destination and if it was the first visit to that geographical area (contingency coefficient = 0.353; $\mathrm{p}=0.000$ ).

Focusing on the All-Inclusive System, Table 5 shows the number of times that each of the respondent tourists had used this holiday system before this trip.

Table 5. Number of times they had used the AIS

\begin{tabular}{|c|c|c|}
\hline Number of times & Cancun & Puerto Plata \\
\hline Never & $16.3 \%$ & $31.4 \%$ \\
\hline 1 time & $33.2 \%$ & $27.2 \%$ \\
\hline 2 times & $42.5 \%$ & $27.7 \%$ \\
\hline $3-5$ times & $8.0 \%$ & $7.1 \%$ \\
\hline More than 5 times & $0.0 \%$ & $6.6 \%$ \\
\hline
\end{tabular}

Source: Own elaboration

According to Table 5, and in relation to the times they have used the AIS, $42.5 \%$ of respondent tourists in Cancun pointed that they had used this system on two occasions while in the case of Puerto Plata $31.4 \%$ said they had never used it. An association was detected between the destination and if it was the first time they used the AIS (contingency coefficient $=78.964 ; \mathrm{p}=0.000$ ).

On the other hand, tourists were asked their opinions about different statements related to the AIS. Table 6 shows such statements scored on a Likert scale of 5 points, with 1 being in strong disagreement; and 5, completely agreeing. 
Table 6. Assessment of different statements related to all-inclusive mode.

\begin{tabular}{|c|c|c|c|}
\hline Item & Cancun & $\begin{array}{c}\text { Puerto } \\
\text { Plata }\end{array}$ & $\begin{array}{c}\mathbf{F} \\
\text { (p-value) }\end{array}$ \\
\hline $\begin{array}{l}\text { In the all-inclusive system, services that are included in the price, } \\
\text { and those which are not included, should be clearly explained to } \\
\text { the consumer. Thus, consumers are fully aware of the extra costs } \\
\text { that they could have. }\end{array}$ & 4.44 & 4.42 & $\begin{array}{c}0.242 \\
(0,623)\end{array}$ \\
\hline $\begin{array}{l}\text { The hotels that have a sufficient financial power to implement this } \\
\text { all-inclusive system should not lower the price and quality, because } \\
\text { the system is not a concept that must be applied to each hotel. }\end{array}$ & 4.32 & 3.75 & $\begin{array}{c}99.169 \\
(0.000) *\end{array}$ \\
\hline $\begin{array}{l}\text { Tourist stays in hotels with all-inclusive systems do not encourage } \\
\text { tourists to go to the city for shopping. Therefore, the increase in } \\
\text { tourism is not reflected in local shops. When tourism is considered } \\
\text { as a whole, it is inevitable that local businesses consider this } \\
\text { system a disadvantage }\end{array}$ & 4.27 & 4.03 & $\begin{array}{c}20.167 \\
(0.000) *\end{array}$ \\
\hline $\begin{array}{l}\text { Tourists spend all their time in the hotel but blame the whole } \\
\text { tourism system for any failure. }\end{array}$ & 4.22 & 3.87 & $\begin{array}{c}42.641 \\
(0.000) *\end{array}$ \\
\hline $\begin{array}{l}\text { Tourists who spend all their time in the hotel do not know the } \\
\text { island and therefore do not have enough information about the } \\
\text { social and historical structure of the island, which is a big problem } \\
\text { in terms of advertising of the country itself. }\end{array}$ & 4.21 & 4.02 & $\begin{array}{c}14.427 \\
(0.000) *\end{array}$ \\
\hline $\begin{array}{l}\text { The all-inclusive system could also cause unfair competition with } \\
\text { other establishments on the island who provide quality service and } \\
\text { who are not in this system }\end{array}$ & 4.21 & 3.76 & $\begin{array}{c}66.624 \\
(0.000) *\end{array}$ \\
\hline $\begin{array}{l}\text { Hotels implementing the all-inclusive system diminish the quality } \\
\text { of services and goods provided to increase profits. Therefore, } \\
\text { employment is largely unskilled, the salary of the staff is very low } \\
\text { and the quality of goods is declining. }\end{array}$ & 4.20 & 3.98 & $\begin{array}{c}20.890 \\
(0.000) *\end{array}$ \\
\hline
\end{tabular}

Source: Own elaboration

* Correlation is significant at level 0.01

As for the opinions of tourists in relation to the AIS, as it is shown in Table 6, it emphasizes that they agree with the statement that consumers know exactly the extra expenses that they will have during the trip and what is included in the price that has been paid. In this sense, this finding supports the conclusion drawn by Özdemir et al. (2012).

As for the positive aspects of the AIS, respondent tourists were asked about a number of issues that are reflected in table 7 . The results are more than $100 \%$ since it was a multiple-choice question. 
Table 7. Positive aspects of the AIS

\begin{tabular}{|c|c|c|}
\hline Issues Raised & Cancun & Puerto Plata \\
\hline This system is very convenient for tourists & $77.0 \%$ & $68.7 \%$ \\
\hline Travellers know the travel budget perfectly well & $35.6 \%$ & $51.6 \%$ \\
\hline The hotel covers all the needs of tourists & $34.8 \%$ & $42.0 \%$ \\
\hline This system provides security for tourists & $19.6 \%$ & $34.4 \%$ \\
\hline This system ensures the quality of service to tourists & $0.3 \%$ & $11.5 \%$ \\
\hline
\end{tabular}

Source: Own elaboration

As for the positive aspects of the AIS, and in accordance with Table 7 , tourists surveyed both in Cancun and Puerto Plata indicated as positive aspects that the AIS is very convenient for tourists and that travellers know the travel budget perfectly well. These results corroborate previous results by Alegre and Pou (2006) and Özdemir et al. (2012). However, they do not agree, as a positive aspect, that this system guarantees the quality of service to tourists. Specifically, this aspect has also been evaluated in the same direction, in previous research to obtain a similar result (Çiftçi et al., 2007; Özdemir et al, 2012.).

As for the negative aspects of the AIS, respondent tourists were also asked different questions that are reflected in Table 8 . The results are more than $100 \%$ since it was a multiple-choice question.

Table 8. Negative aspects of the AIS

\begin{tabular}{|c|c|c|}
\hline Question & Cancun & Puerto Plata \\
\hline The system encourages not leaving the hotel & $64.0 \%$ & $53.1 \%$ \\
\hline The system limits contact of tourists with the local population & $52.0 \%$ & $47.3 \%$ \\
\hline This system does not reveal the real culture of a geographical & $9.0 \%$ & $28.2 \%$ \\
\hline $\begin{array}{c}\text { Local agents of the destination do not obtain sufficient } \\
\text { benefits from the arrival of tourists to this hotel }\end{array}$ & $6.6 \%$ & $18.9 \%$ \\
\hline This system may limit the external connections to the hotel & $6.3 \%$ & $31.7 \%$ \\
\hline
\end{tabular}

Source: Own elaboration

According to Table 8, the main negative aspects pointed by the tourists surveyed in both geographical areas are that this system encourages not leaving the hotel and that the system limits contact with the local population, an aspect that was also evaluated in the same direction by Çiftçi et al. (2007). However, at the destination of Cancun, respondent tourists 
do not consider that the AIS does not allow to know the real culture of a geographical area as only $6.3 \%$ of tourists surveyed in this geographical area have agreed with this statement, whereby tourists feel they can also learn about the culture of this area through different types of excursions. In this sense, Cancun, in addition to its beaches, is also configured as an attractive destination for knowledge of cultural, natural and historical elements of the site.

Regarding the assessment on the different variables related to the hotel where they stayed, results rated on a Likert scale of 5 points, 1- being the worst; and 5 the best, are collected in Table 9. In terms of these variables, we have distinguished between those that refer to the hotel itself and those that refer to the environment where the hotel is located.

Table 9. Rating aspects of the hotel

\begin{tabular}{|c|c|c|c|}
\hline Variable & Cancun & Puerto Plata & $\begin{array}{c}\text { F (significance } \\
\text { level) }\end{array}$ \\
\hline Inside the hotel & & & \\
\hline Shows & 4.14 & 3.91 & $21.827(0.000)$ \\
\hline Customer Service & 3.99 & 3.87 & $5.916(0.015)$ \\
\hline Food & 3.98 & 3.79 & $13.000(0.000)$ \\
\hline Beverages & 3.98 & 3.82 & $8.444(0.004)$ \\
\hline Rooms & 3.96 & 3.77 & $11.325(0.001)$ \\
\hline Outside the hotel & & & \\
\hline Beaches & 4.20 & 3.99 & $21.582(0.000)$ \\
\hline Excursions outside the hotel & 4.12 & 3.88 & $23.617(0.000)$ \\
\hline Cleanliness of the surrounding area & 4.07 & 3.79 & $28.801(0.000)$ \\
\hline Commercial Areas & 4.03 & 3.77 & $23.740(0.000)$ \\
\hline Sports activities & 4.02 & 3.80 & $19.535(0.000)$ \\
\hline
\end{tabular}

Source: Own elaboration

According to Table 9, what is most valued by tourists in both destinations of $\mathrm{AI}$ hotels is the shows that are held within the hotel itself and what is least valued (although with quite an important valuation as well) is the actual hotel rooms. On the other hand, with respect to the surroundings of the hotel's location, what is most valued by tourists of both destinations is the beaches, while the least valued is the sports activities that can be enjoyed outside the hotel.
About tourist satisfaction with the trip, rated on a Likert scale of 5 points, being 1-very unsatisfied; 5-very satisfied, in the case of tourists surveyed in Cancun, the result was 3.83 and in the case of tourists surveyed in Puerto Plata the result was 4.05. An association was detected between the level of satisfaction and the number of times that the AIS had been used in both destinations, Cancun (Pearson Chi-square coefficient $=51,236 ; \mathrm{p}=0.000)$, and Puerto Plata (Pearson Chi-square coefficient $=88,495 ; \mathrm{p}=0.000)$. 


\section{CONCLUSIONS}

In recent years, the AIS has developed and consolidated in various tourist destinations as a form of tourist enjoyment of holidays knowing in advance the price of the trip. In this system, the hotel is a key element since most of the time tourists stay within their own hotel establishment where they have all they need to enjoy their holiday.

In this paper, we present an analysis of the AIS in two destinations that are consolidated and that compete with each other, Puerto Plata in Dominican Republic and Cancun in Mexico. The results of the research show how tourists surveyed in both locations show a high level of satisfaction with the trip made. Furthermore, as the positive aspect that is most valued by AIS tourists, it can be highlighted that this system is very convenient for tourists, while as the negative aspect, it can be highlighted that this system provides no incentive to leave the hotel and

\section{REFERENCIES}

Alegre, J., \& Pou, L. (2006). El paquete turístico de todo incluido: un análisis de sus implicaciones económicas para el caso de las Islas Baleares. Mallorca: Universitat de les Illes Balears.

Anderson, W. (2010). Determinants of all-inclusive travel expenditure. Tourism Review. 65(3), 4-15.

Anderson, W. (2012). Analysis of AllInclusive tourism mode in the Balearic Islands. Tourismos: An international multidisciplinary journal of tourism. 7(1), 309-323.

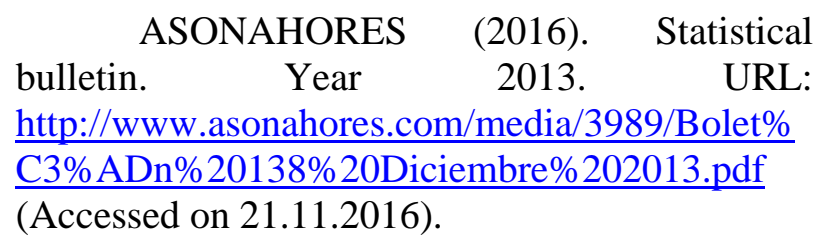

therefore limits the knowledge of the local culture during the trip.

These results can help hotel management, especially by improving the aspects that contribute to improving the quality of the service. Also, you can work from the management of the hotels in the place of the complementary offer, once known, the motivations and valuations of the visitors. These aspects are fundamental to offer a quality and diversified offer.

We believe that the main limitation of this research is in the time period in which the surveys took place given that the results to be obtained in these time periods may differ due to different tourist profiles.

As a future line of research, we consider that there should be an analysis of the relationship between the all-inclusive hotels, usually belonging to international hotel chains, and small and medium-sized local companies supplying products for hotels.

Ayik, T.; Benetatos, T., \& Evagelou, I. (2013). Tourist consumer behaviour insights in relation to all inclusive hotel resorts. The case of Anatalya, Turkey. Thesis.

Babinger, F. (2012). Tourism facing the challenge of recurring natural hazards: a view from Cancun. Investigaciones Geográficas, 78, 75-88.

Chambers, D., \& Airey, D. (2001). Tourism policy in Jamaica: A tale of two governments. Current issues in Tourism, 4(2-4), 94-120.

Chapman, A., \& Speake, J. (2011). Regeneration in a mass-tourism resort: the changing fortunes of Bugibba, Malta. Tourism Management, 32, 482-491.

Çiftçi, H.; Düzakin, E., \& Önal, Y. B. (2007). All inclusive systems and its effects on the Turkish tourism sector. Problems and perspectives in management, 5 (3), 269-285. 
Çizel, R. B.; Çizel, B.; Sarvan, F., \& Özdemir, B. (2013). Emergente and spread o fan all-inclusive system in the Turkish tourism sector and strategic responses of accommodation firms. International Journal of Hospitality \& Tourism Administration. 14, 305-340.

Condratov, I. (2014). All inclusive system adoption within Romanian tourist sector. Ecoforum, 3 (1), 78-83.

Espinosa-Coria, H. (2013). El origen del proyecto turístico Cancún, México. Una valoración e sus objetivos iniciales a 42 años de su nacimiento. Revista Limina, Estudios Sociales y Humanísticos, 11 (1), 154-167.

Finn, M., Elliott-White, M., \& Walton, M. (2000). Tourism and leisure research methods: Data collection, analysis and interpretation. Harlow: Pearson Education.

Gormsen, E. (1982). Tourism as a development factor in tropical countries. A case study of Cancun, Mexico. Applied Geography and Development, 19, 46-63.

González Herrera, M., \& Palafox Muñoz, A. (2007). Hoteles todo incluido en Cozumel: aproximación hacia la sustentabilidad como elemento competitivo del destino. Turismo em Análise, 18(2), 220-244.

Kozak, M. (2002). Comparative analysis of tourist motivations by nationality and destinations. Tourism management, 23, 221-232.

Issa, J.J., \& Jayawardena, C. (2003). The all-inclusive concept in the caribbean. International Journal of Contemporary Hospitality management, 15(3), 167-171.

Lagunas Puls, S., Ramírez Pacheco, J.C., \& Sonda de la Rosa, R. (2014). Características para la futura oferta de alojamiento turístico en Cancún, México. Análisis probabilística y regresión logística. Estudios y Perspectivas en Turismo, 23, 101-114.
Moreno Gil, S., Celis Sosa, D.F., \& Aguiar Quintana, T. (2002). Análisis de la satisfacción del turista de paquetes turísticos respecto a las actividades de ocio en el destino: el caso de República Dominicana. Cuadernos de Turismo, 9, 67-84.

Nunnally, J., \& Bernstein, I. (1994). Psychometric Theory. New York: McGraw-Hill.

Özdemir, B., Çizel, B., \& Çizel, R.B. (2012). Satisfaction with all-inclusive tourism resorts: the effects of satisfaction with destination and destination royalty. International Journal of Hospitality \& Tourism Administration, 13, 109130.

Roessingh, C., \& Duijnhoven, H. (2005). Small entrepreneurs and shifting identities: the case of tourism in Puerto Plata (Northen Dominican Republic). Journal of Tourism and Cultural Change, 2 (3), 185-202.

SEDETUR (2014). Tourist activity. URL: http://sedetur.qroo.gob.mx/estadisticas/indicador es/Indicadores\%20Turisticos\%202013.pdf (Accessed on 19.10.2016).

Smith, T., \& Spencer, A. (2011). Predictors of value for money in Jamaican Allinclusive hotels. International Journal of Humanities and Social Sciences, 1 (4), 93-102.

Torres, R. (2002). Cancun's tourism development from a Fordist spectrum of analysis. Tourist Studies, 2 (1), 87-116.

Wong, C.-K. S., \& Kwnog, W-Y. Y. (2004). Outbound tourists' selection criteria for choosing all-inclusive package tours. Tourism Management, 25, 581-592. 